\title{
E-Learning Model for Problem Based Learning on Heat and Thermodynamic Topics in High School
}

\author{
Fauzi Bakria $^{\text {a) }}$, Sunaryo ${ }^{\text {b) }}$, Velinda Finka Irawan ${ }^{\text {c) }}$, Dewi Muliyati ${ }^{\text {d) }}$ \\ Physics Education Department, Faculty of Mathematics and Natural Sciences, \\ Universitas Negeri Jakarta, Rawamangun, Jakarta, Indonesia, 13220
}

a)fauzi-bakri@unj.ac.id, ${ }^{b}$ sunaryo@unj.ac.id, ${ }^{c}$ oreniaginkairawan@gmail.com, d) dmuliyati@unj.ac.id

\begin{abstract}
The development of information and communication technology (ICT) in the 21 st century makes it easier for students to be more active in the learning process. Physics learning materials are needed to support the problem-based learning process in high school. This study aims to produce e-learning models for problem-based learning on Heat and Thermodynamics topics. The result shows media can be used in learning in high school class XI. We uses the research and development method, with the Dick and Carey model. The study was conducted in a digital media laboratory, Physics Education Department of Universitas Negeri Jakarta from January to June 2018. E-Learning models have been produced for problem-based learning in the topic of Heat and Thermodynamics. This WordPress-based ELearning model can display physics material enriched with images, graphics, animations, simulations, and videos. Students are facilitated to understand the concepts learned. The elearning model is equipped with assessment tools that can be used online. Students are facilitated to learn independently without limited space and time. The E-learning model developed was also equipped with discussion groups in the form of chats for all registered users. The media validation obtained the results of system evaluation, content, and e-learning infrastructure with 78.9 points average. The material validation gives an 81.55 rating. Concerning media and material, e-learning media is declared feasible as a medium for selflearning. The e-learning model for problem-based learning is feasible to use to train the ability to critical thinking, creative thinking, collaborative, and communicate for students in high school.
\end{abstract}

Keywords: e-learning, wordpress, problem based learning, heat and thermodynamic

\section{INTRODUCTION}

The progress of Information and Communication Technology (ICT) has changed the pace of information access acceleration. The interactions that have occurred have been made easier and more diverse (Husain 2014). The progress of ICTs has created new methods of learning. These new methods can integrate into learning materials. Learning can be displayed contextually (Rahmayanti 2015). The use of ICT has changed the 21 st century learning process a lot. With the help of ICT the formal learning process is not only carried out in the classroom but can be carried out the classroom outside (Zubaidah 2016).

ICT integration also supports student-centered learning processes. Students in the 21 st century are required to: (1) get used to finding their information; (2) able to identify and formulate the problems; (3) able to work effectively in a groups; and (4) have high creativity (Sani 2014). At present the role 
of teachers in the learning process shifts to a facilitator for students. Teachers are required to be competent in designing learning following the character of 21 st century students. In preparing teachers must combine the competencies that achieved by students with the demands of 21 st century skills (Yadzi 2012).

The implementation of learning needs to synergize between teachers and students. Teachers need to have skills in integrating ICT in the learning process. Teachers must also be skilled in the use of ICT media (Harianto 2016). Students need to have learning and innovation skills, skills in using technology and information media, also can work and survive by using life skills (Haryono 2017). Students need to develop skills known as 4C (communication, collaboration, critical thinking and problem solving, and creativity and innovation) (Wijaya 2016). The implementation of ICT in learning planning is certainly inseparable from the learning model chosen in learning plan. The problem-based learning model is one of the ideal learning models to train the ability of students to critical thinking, creative thinking, collaboratively, and communicate (Zubaidah 2016).

One form of ICT application in education is the implementation of the learning process by utilizing various electronic learning resources. The ICT can utilize us the internet network and unlimited by space and time. The implementation of ICT in the learning process integrated in a system that we know as E-Learning (Nugraheni 2009). E-Learning is learning by utilizing computer and internet technology (Silahuddin 2015). In addition to technological elements, developing ELearning must pay attention to the elements of pedagogy, because learning is a comprehensive activity, including cognitive, affective, and psychomotor (Aunurrahman 2009). E-learning designers also need to pay attention the needs of their users so that the website created can be used publicly (Taylor 2002). Visual factors on the website are also important to note to attract many users (Papachristos 2013).

The technical development of E-Learning divided into two forms, namely LMS (Learning Management System) and CMS (Content Management System) (Trisnaningsih 2016). One of the most popular CMS in the world is WordPress (Sudaryono 2016). WordPress has several advantages including free, open source based, easy to operate, so many plugins are always developing, SEO friendly, and can be used offline (Leone 2013).

\section{RESEARCH METHODOLOGY}

This study aims to produce media e-learning in the form of WordPress-based for Heat and Thermodynamics topics. The resulting media used for class XI high school student's with problembased learning. This study uses the research and development method, with the Dick and Carey model. The Dick and Carey research and development model consists of ten steps, but only the first nine steps are carried out in our study (Dick \& Carey 2015), as follows:

1) Identify instructional goals and objectives. Conduct an analysis on basic competencies about heat and thermodynamics that must be possessed by high school students.

2) Complete instructional analysis. Analyze concepts and material principles relevant to the heat and thermodynamic competencies that high school students must have.

3) Determine the entry behaviors and learner characteristics. Analyze the learning characteristics of students, the basic abilities of students, and the competencies that must be possessed by students.

4) Write the performance objectives. Formulate learning objectives to be achieved by students after learning on the media developed.

5) Develop the criteria of referenced e-learning assessment instruments. Arrange the grid and grading instruments to measure the achievement of basic competencies about heat and thermodynamics by high school students.

6) Develop instructional e-learning strategies. Develop learning plans and the blue print of learning media using problem-based learning.

7) Develop and choose learning materials and online activities. Develop learning materials based on the blue print. Choosing videos, images, graphics, animations, and simulations that are relevant to problem-based learning material. 
8) Design and implement formative evaluations. Develop instruments for assessing the feasibility of e-learning media and the suitability of the material presented for basic heat and thermodynamic competencies in problem-based learning. Conduct the e-learning media feasibility tests for problem-based learning to material experts, media experts, and e-learning media users, namely teachers and students in high school.

9) Carry out revisions or improvements. Improving e-learning media by the input of material experts, media experts and e-learning media users

Research and development was carried out in the digital media laboratory in FMIPA Universitas Negeri Jakarta. Field tests conducted in several high schools in Jakarta. Research time January - June 2018. Feasibility validators are learning material experts and e-learning media experts from the Physics Education Department of Universitas Negeri Jakarta, and material experts are lecturers from the Physics Department of Universitas Negeri Jakarta.

\section{RESULTS AND DISCUSSION}

\section{The Design of E-Learning Model}

WordPress-based E-Learning model in the Heat and Thermodynamics topics consists of the following components.

\section{Homepage}

We can access the WordPress-based E-Learning model on Heat and Thermodynamics topic through http://smartlearning.fisika-unj.ac.id/11a. The following will describe the e-learnig product description.

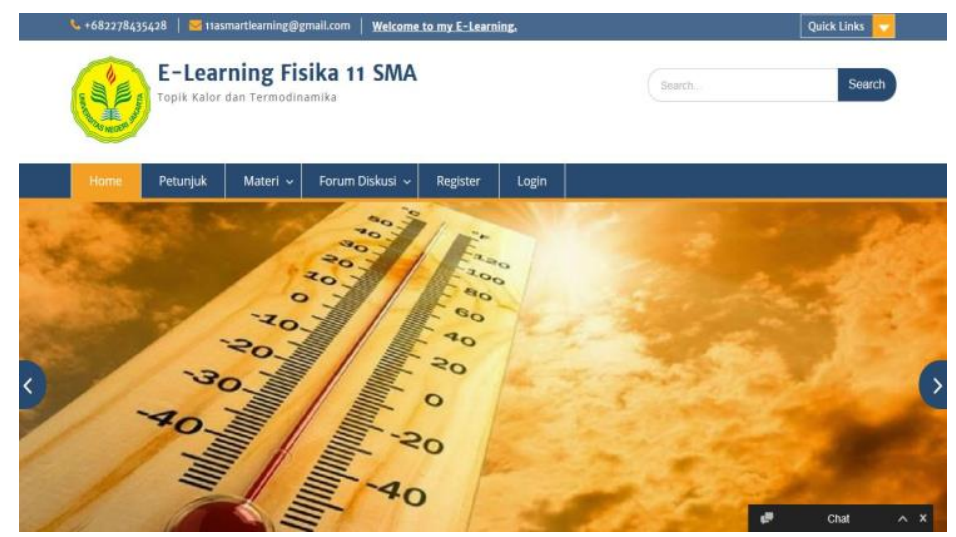

(a)

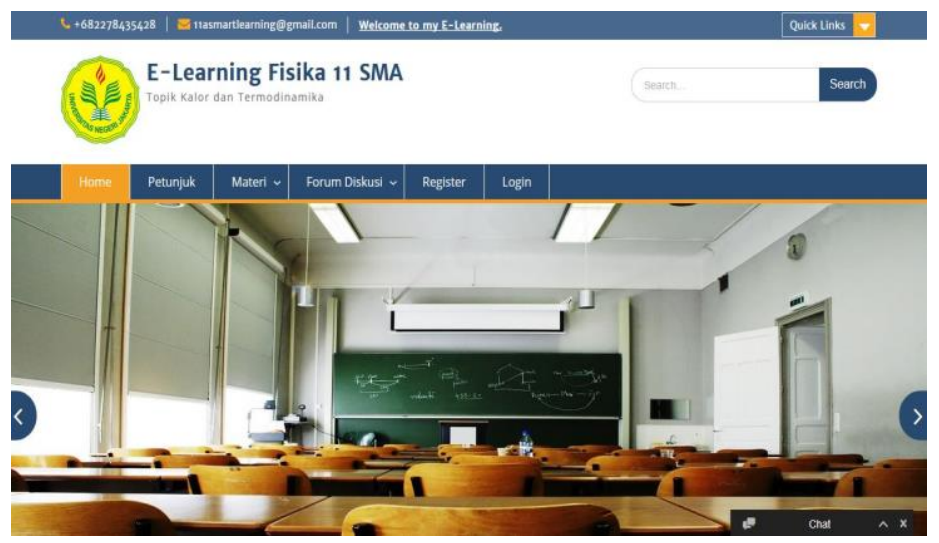

(b)

FIGURE 1. Display the Homepage of E-Learning. 

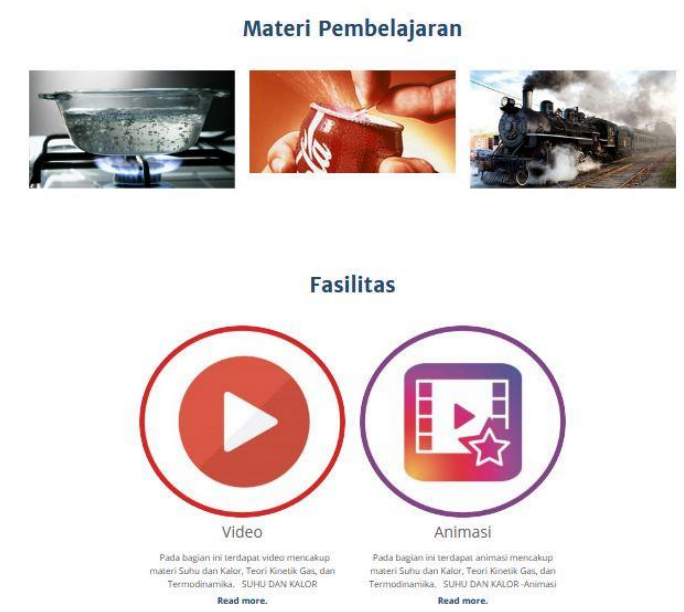

(a)

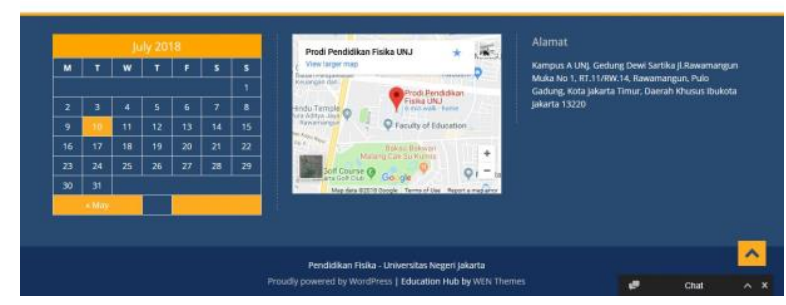

(b)

FIGURE 2. Display Homepage after scrolling: (a) material, facilities, and (b) widgets.

\section{Instructions page}

The instructions page is a web page that contains instructions on how to use web e-learning, such as how to register, logging on, and how to use the facilities provided by the website.

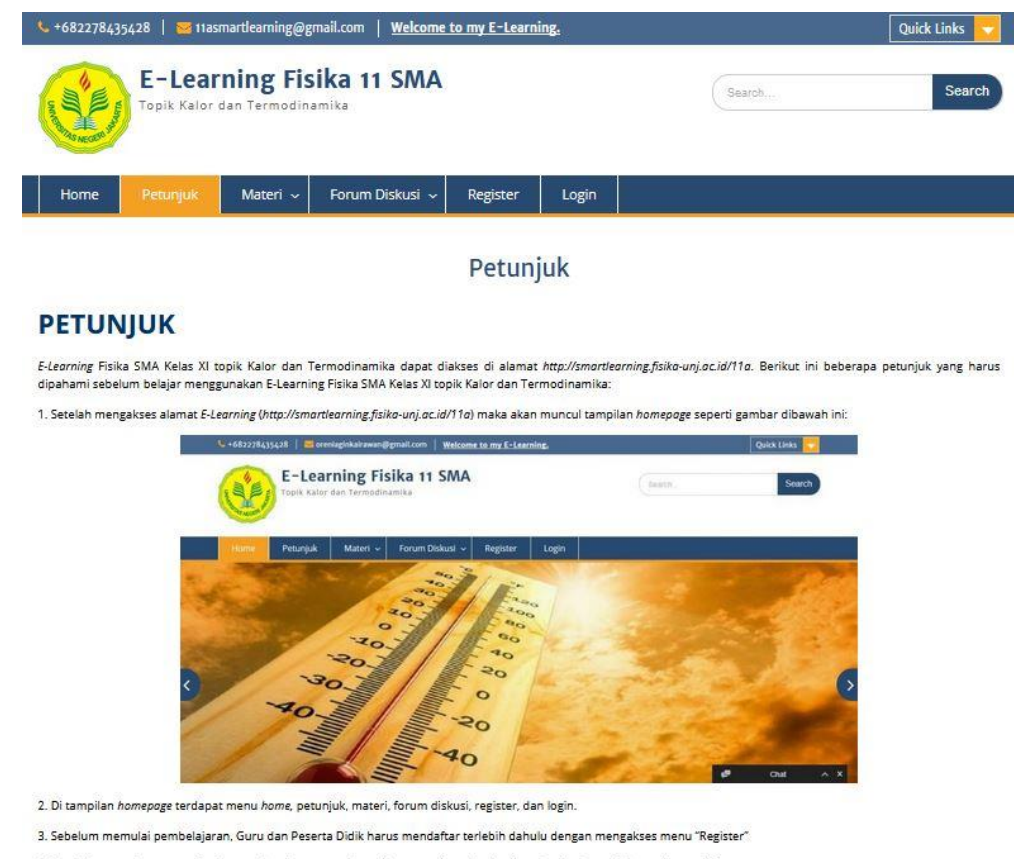

FIGURE 3. Display instructions page. 


\section{Register dan login page}

Register is a web page that contains a column to register as a web user. Login is a web e-learning page that is used to enter the web to access the facilities provided by the website.
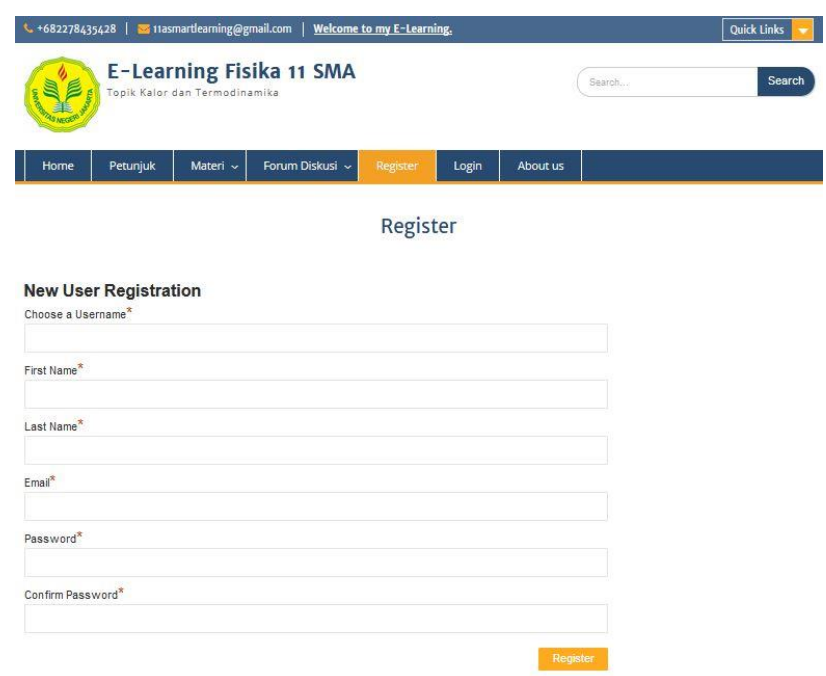

FIGURE 4. Register display.

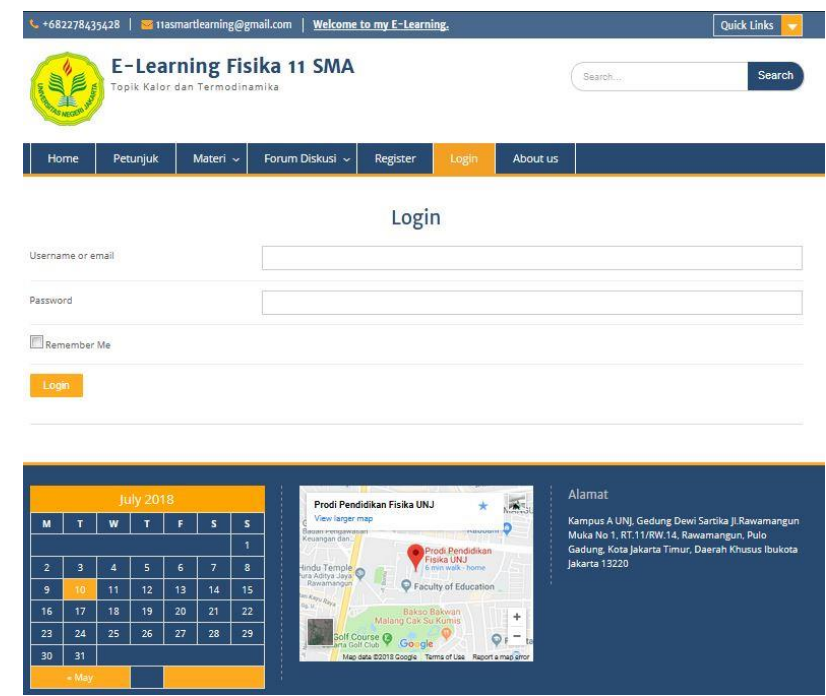

FIGURE 5. Login display. 


\section{About us}

About us is a page that contains information about the web, such as what material is provided, administrators, and consultants.

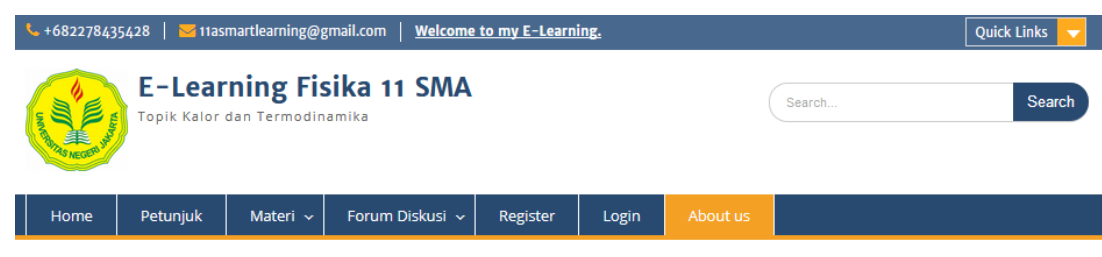

About us

SELAMAT DATANG DI E-LEARNING FISIKA SMA KELAS XI

Apa itu WordPress?

WordPress merupakan salah satu CMS (Content Management System) yang paling popular. CMS WordPress bersifat open source, yang dapat dimanfaatkan untuk membuat sebuah blog atau web. CMS WordPress memiliki beberapa kelebihan di antaranya adalah mudah dioperasikan, tersedia banyak plugin yang selalu berkembang, tema yang bervariasi, SEO friendly, mendukung banyak
tentang HTML, hosting, PHP, dan javascript.

Materi yang dapat di akses di E-Learning Fisika SMA:
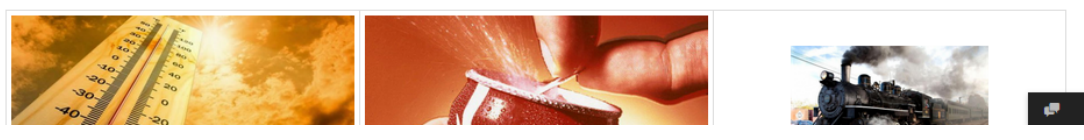

FIGURE 6. About us display page.

\section{Physics Material}

On the physics material page displays the physical material contained in E-Learning. Users can access the desired physics material after logging in.

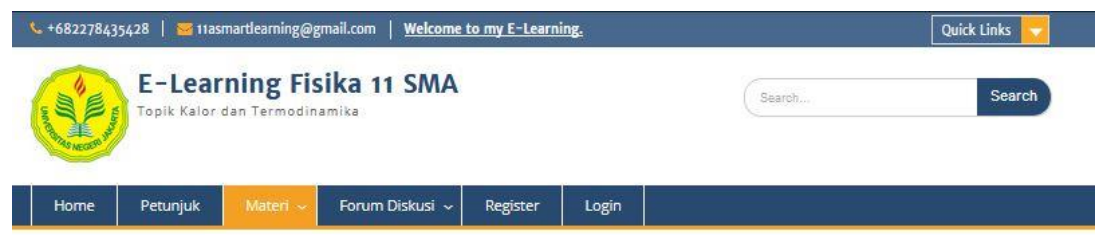

LP Courses

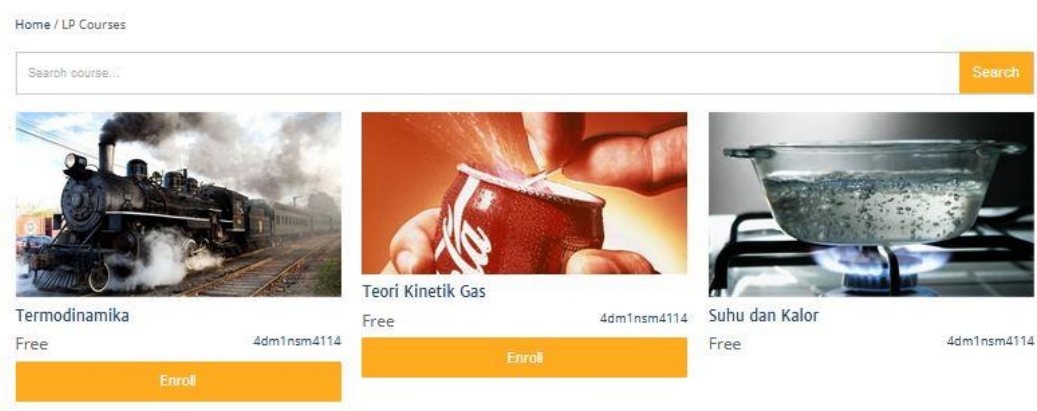

FIGURE 7. Physics material page display.

Physics material are presented following the stages of problem-based learning. The first stage is to display a video about a problem that is the subject of the material to be studied. Students orient themselves to the problems presented. Students are given several questions to be able to formulate hypotheses. Teachers can see students' hypotheses in the chained quiz section.

The second stage, students are organized for collaborative learning. Media e-learning provides a discussion forum between groups to understand the material they are learning. The teachers can see 
the activities of students in discussion forums on e-learning media. This stage will help students to collaborate and communicate under the material studied.

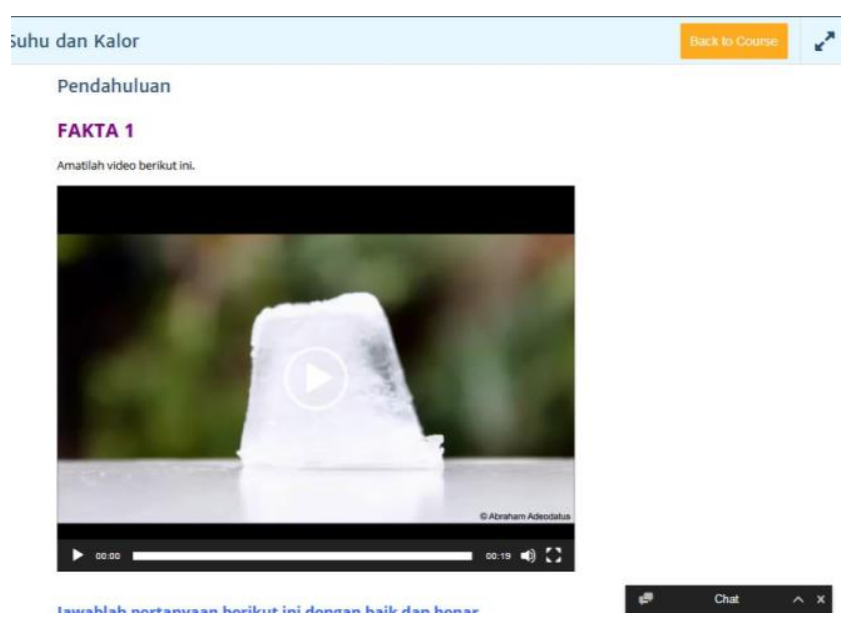

(a)

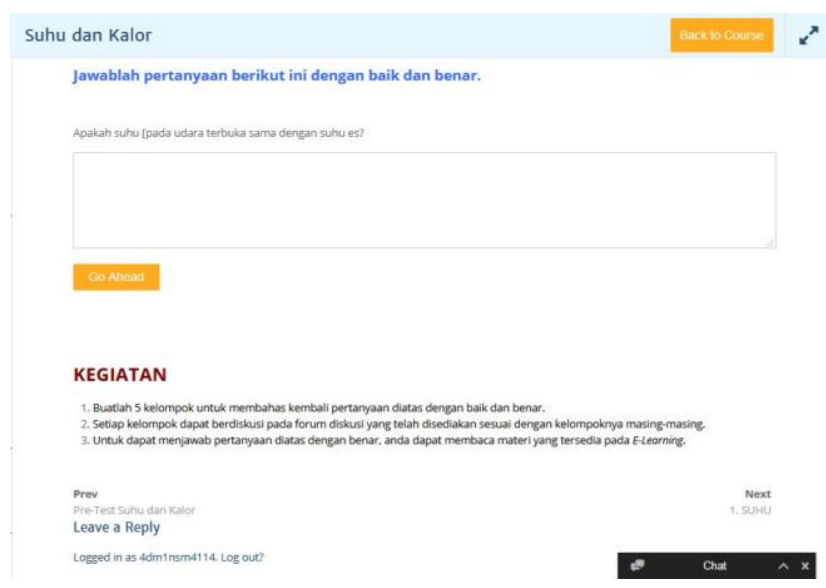

(b)

FIGURE 8. Preliminary display of material; (a) Orientation to the Problem, (b) Student Organization for Learning.

The third stage, investigation and data collection. Information is presented in the form of literature studies, simulations, observations through video, animation. Students are expected to get complete information to answer the problems presented at the beginning of learning.

The fourth stage, presents the results of the discussion. Students learn to write learning conclusions in the dialog box provided. Students are required to answer a series of questions that measure the level of understanding of the material. This activity is presented in the Quiz and Survey Master section. 


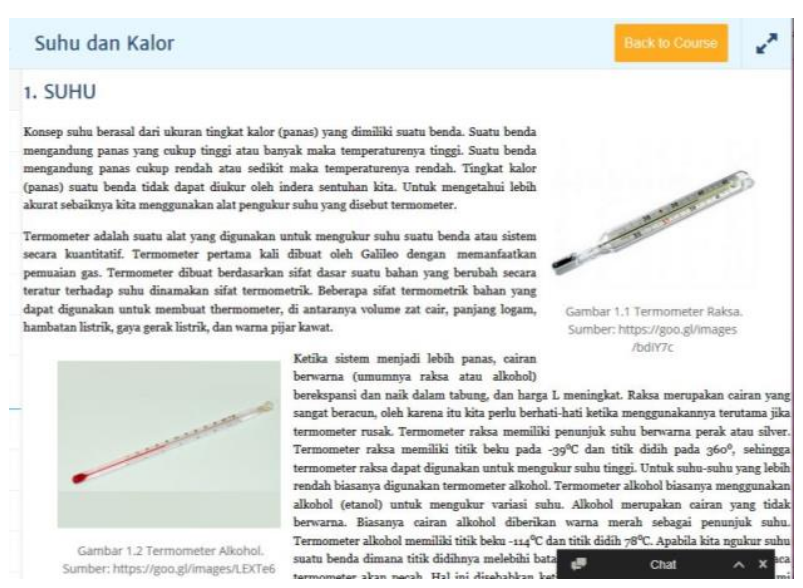

FIGURE 9. Data Collection display.

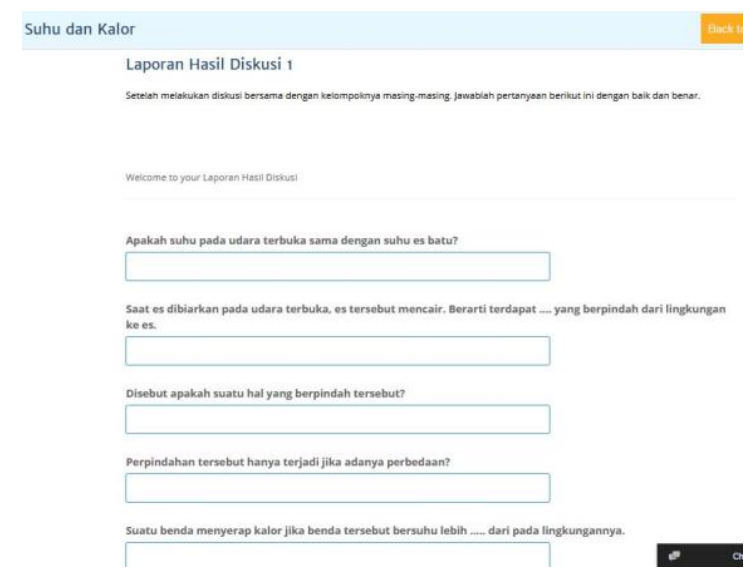

FIGURE 10. Result of discussion display.

The fifth stage, reflection and evaluation. This section is at the end of the chapter. Students are given evaluation questions according to the indicators of achievement of learning and achievement of learning completeness. The teachers can see the work of students and the students concerned. Learners can reflect on which parts have good understood and the parts that have not yet completed in their learning.

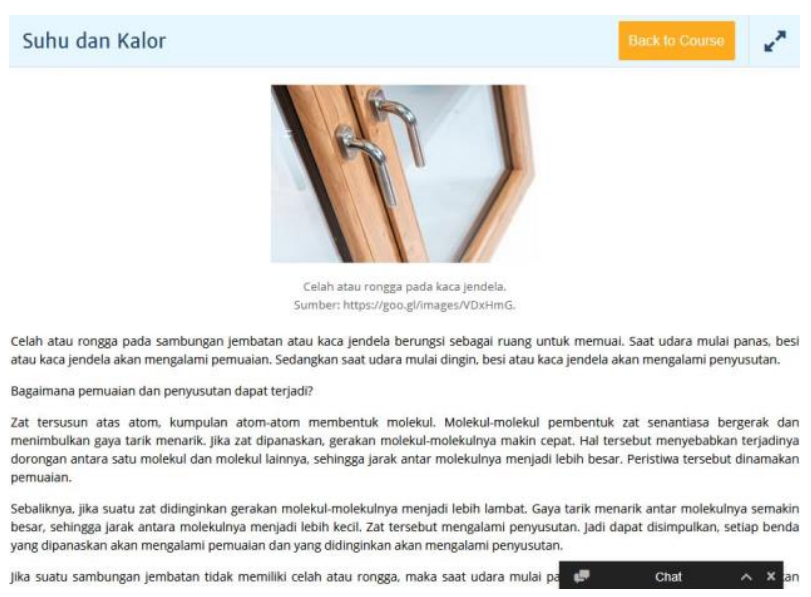

FIGURE 11. Evaluation stage display. 


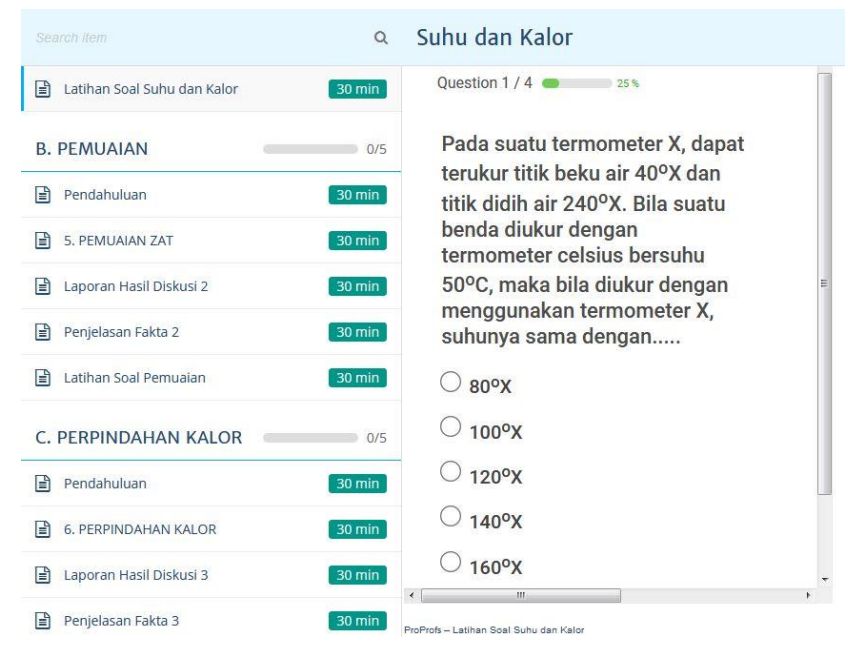

FIGURE 12. Problem display.

\section{Formative Evaluation}

Formative evaluation of E-Learning media was conducted to assess the feasibility of the media. The feasibility of e-learning media is assessed based on instruments of media feasibility and instruments of material feasibility.

Several assessments of e-learning model have been carried out using instruments that include elearning systems, e-learning content and e-learning infrastructure by digital learning media experts. In the second assessment, the expert assesses that all components have been declared feasible and the media can be accepted as e-learning model.

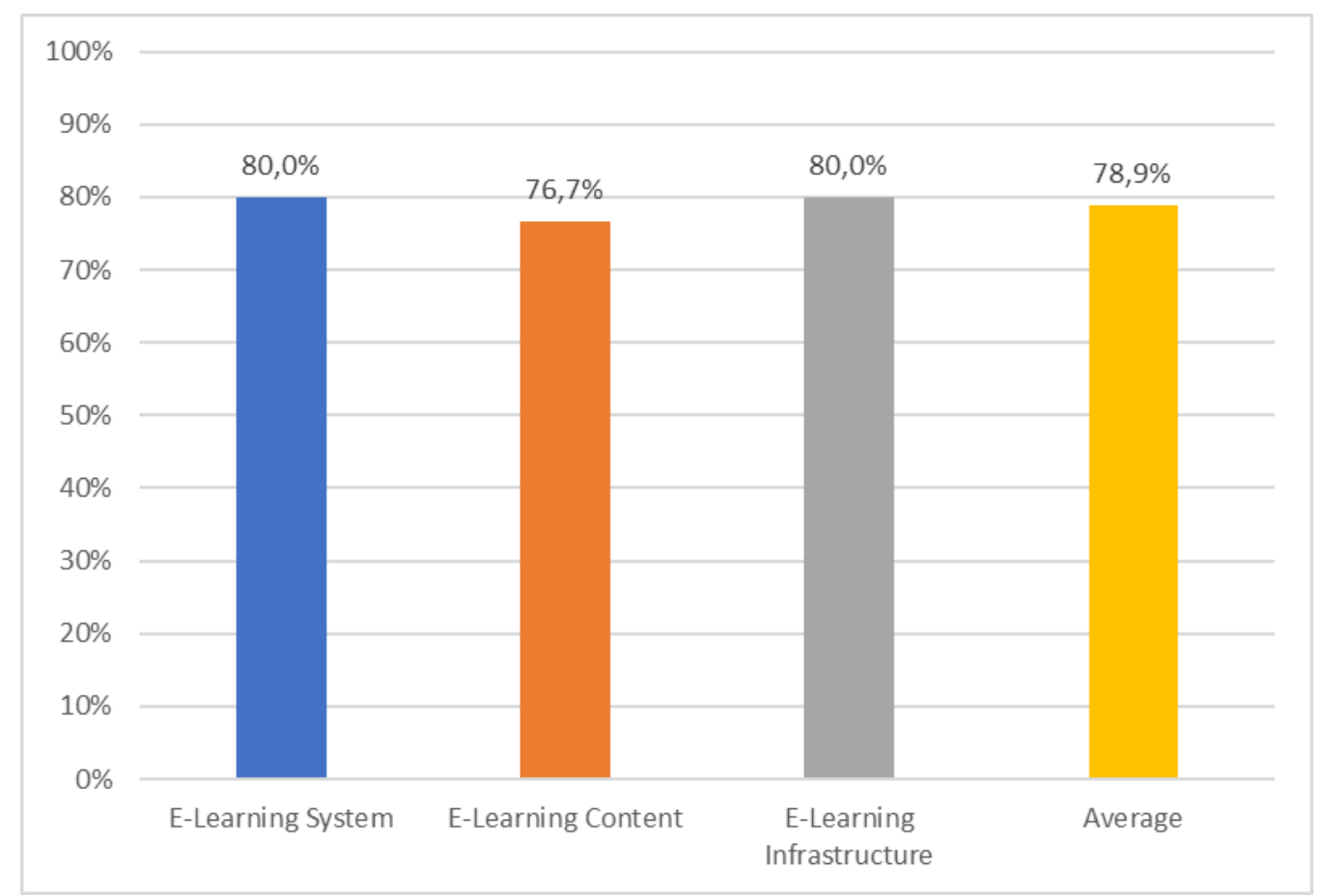

FIGURE 13. Media Feasibility Validation Results

Physics material on e-learning model is assessed by physicists from the Physics Department of Universitas Negeri Jakarta. The results of the assessment were carried out with a Likert scale questionnaire. The components assessed were: material requirements in PBL, scope of physical material, and suitability of each component of e-learning (literature studies, videos, animations, simulations, images, graphics, material exposure). The assessment was conducted on learning for 
chapters on Temperature and Heat, Kinetic Theory of Gas, and Thermodynamics. In the first assessment, the material expert provided input for improvement in several parts. In the second assessment, scores were given as in the following graph and were declared feasible to be used for learning in high school.

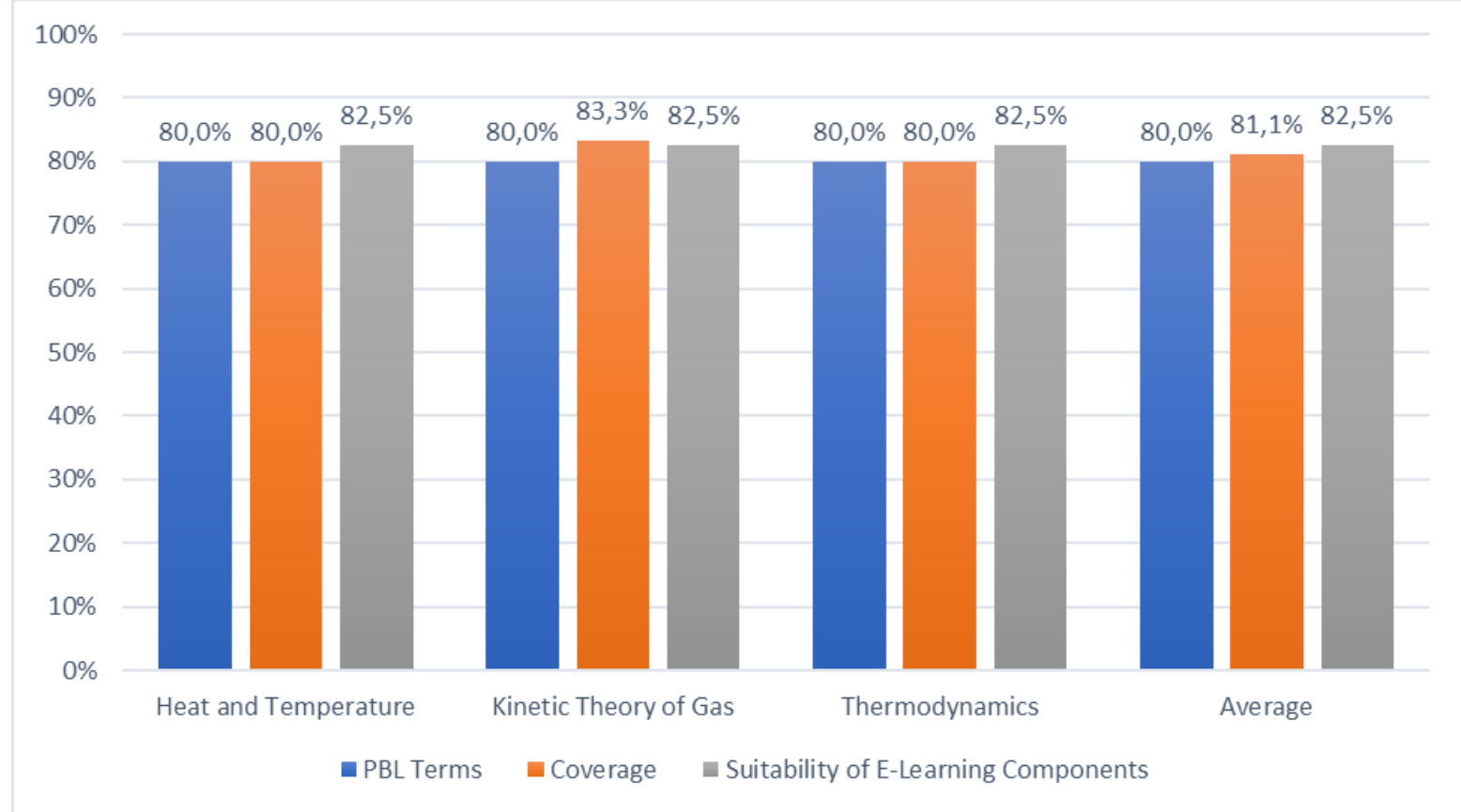

FIGURE 14. Material's Feasibility Validation Results

For the learning process presented in the e-learning model, getting the results of an assessment that is good and appropriate according to the learning expert. The assessment was conducted with a Likert scale instrument to assess PBL material presentation, learning activities and learning assessment. Assessment was carried out for chapters of Temperature and Heat, Kinetic Theory of Gas, and Thermodynamics topics. The assessment for the gas kinetic theory chapter gets a perfect score, while for the Thermodynamics chapter the presentation of material is PBL, and the learning assessment gets perfect scores.

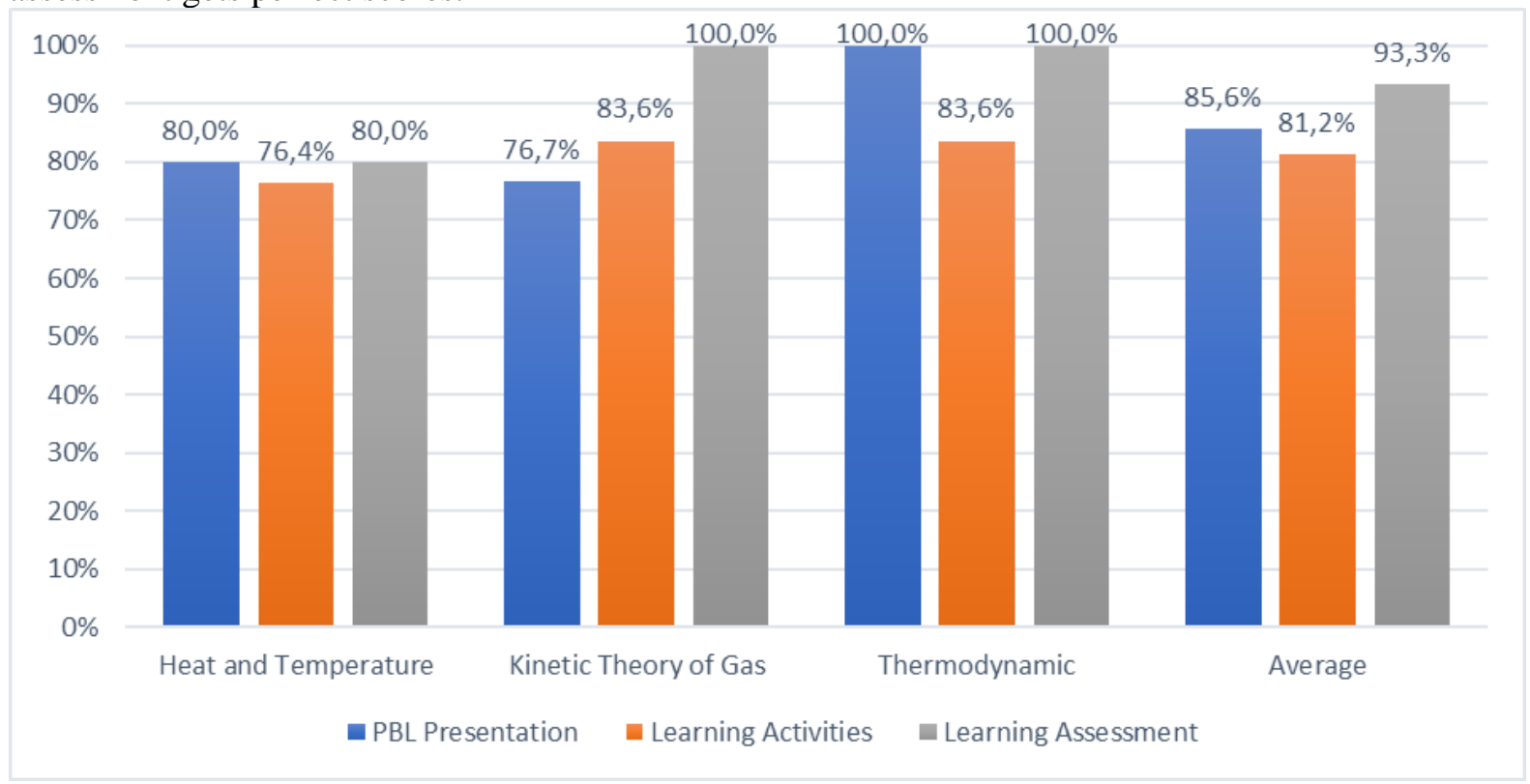

FIGURE 15. Results of Validation of Learning Feasibility 
Field testing of e-learning models is carried out by the teacher as a user. The assessment was carried out by three teachers from 3 different high schools. The assessment includes exposure to material on e-learning media, display of e-learning models, e-learning exposure, and use of language in e-learning models. Teachers argue that the model is very good and can be used as an e-learning model for problem-based learning in high school.

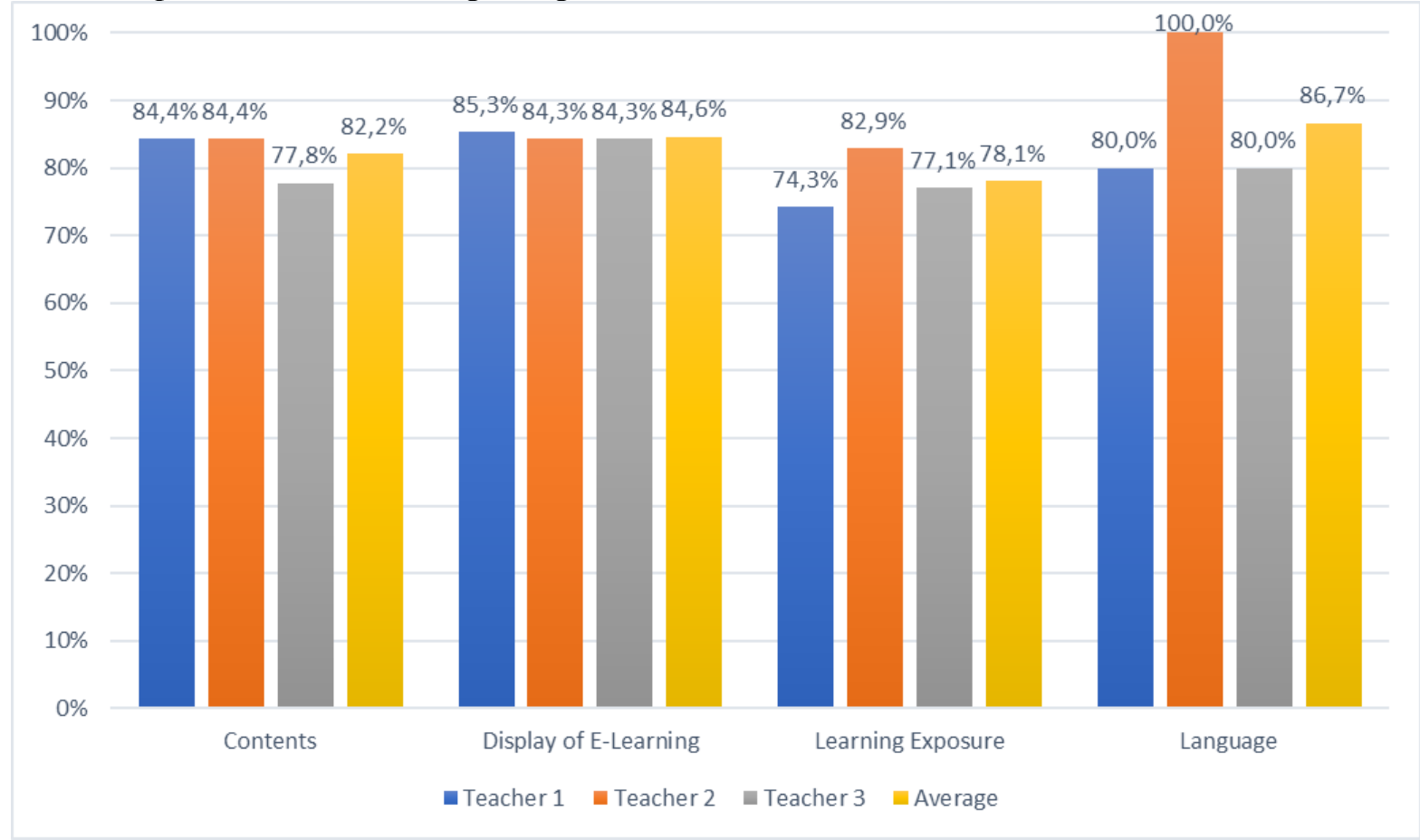

FIGURE 16. Results of e-Learning Model Assessment by the Teacher as User

The e-learning model produced is following the 21st century learning model. The e-learning model facilitates students to: (a) get used to finding their information; (2) able to identify and formulate problems; (3) able to work effectively in groups; and (4) have high creativity (Sani 2014). The e-learning model also fulfills the elements of pedagogy (Aunurrahman 2009). The problembased learning design that is displayed, also helps students to think critically, creatively, collaborate and communicate, according to the 21 st century learning model (Wijaya 2016).

\section{CONCLUSIONS}

Based on the results of formative evaluations by media and material experts, it was concluded that the E-Learning model for problem-based learning in the Heat and Thermodynamics material was considered feasible to use by class XI high school students. Students are guided to learn independently by the demands of 21 st century learning. The problem-based learning design that is displayed, also helps students to think critically, creatively, collaborate and communicate.

\section{REFERENCES}

Aunurrahman 2009, Belajar dan Pembelajaran, Alfabeta, Bandung.

Dick, W, Carey, L, Carey, JO 2015, The Systematic Design of Instruction, Pearson, Boston.

Harianto, I, Hidayat, A, Koes, S 2016, 'Analisis Perencanaan Pembelajaran Guru Fisika SMA dalam Mengintegrasikan Keterampilan Berpikir Kreatif Siswa', Pros Semnas Pend. IPA Pascasarjana $U M$, vol 1, pp. 301-307.

Haryono 2017, 'Teknologi Pendidikan dan Pembelajaran Abad 21', Prosiding Seminar Nasional Teknologi Pendidikan, pp. 425-436. 
Husain, C 2014, 'Pemanfaatan Teknologi Informasi dan Komunikasi dalam Pembelajaran di SMA Muhammadiyah Tarakan', Jurnal Kebijakan dan Pengembangan Pendidikan, vol. 2, no. 2, pp. 184-192.

Leone, S, Spindler, A, Norrie, MC, McLeod, D 2013, 'Integrating Component-Based Web Engineering Into Content management System. Springer-Verlag Berlin Heidelberg', ICWE LNCS vol. 7977, pp. 37-51.

Nugraheni, E 2009, 'Peran dan Kompetensi Guru dalam E-Learning', Jurnal Pendidikan, vol. 10, no. 2, pp. 95-104.

Papachristos, E, Avouris, N 2013, 'The Influence of Website Category on Aesthetic Preferences', IFIP International federation for Information Processing, INTERACT, part.1 LNCS, vol.8117.

Rahmayanti 2015, 'Penggunaan Media IT dalam Pembelajaran', Jurnal Ilmiah CIRCUIT, vol. 1, no. 1, pp. 85-97.

Sani, RA 2014, Pembelajaran Saintifik untuk Implementasi Kurikulum 2013, Bumi Aksara, Jakarta.

Silahuddin 2015, 'Penerapan E-Learning dalam Inovasi Pendidikan', Jurnal Ilmiah CIRCUIT, vol. 1, no. 1 , pp. 48-59,

Sudaryono 2016, Metode Penelitian Pendidikan: Pendekatan Kuantitatif, Kualitatif, dan R\&D, Alfabeta, Bandung.

Taylor, MJ 2002, 'A User Centered Website Development Approach', IFIP International federation or Information Processing.

Trisnaningsih, S 2016, 'Pengembangan E-learning Management System Quipper School pada Pembelajaran Materi Sistem Pertahanan Tubuh untuk Meningkatkan Motivasi dan Hasil Belajar Siswa Kelas XI di SMA Negeri 3 Yogyakarta', Jurnal Pendidikan Biologi, vol. 5, no. 6, pp. 2836.

Wijaya, EY, Sudjimat, DA, Nyoto, A 2016, 'Transformasi Pendidikan Abad 21 Sebagai Tuntutan Pengembangan Sumber Daya manusia Di Era Global', Prosiding Seminar Nasional Pendidikan Matematika, vol. 1, pp. 263-278.

Yadzi, M 2012, 'E-learning Sebagai Media Pembelajaran Interaktif Berbasis Teknologi Informasi', Jurnal Ilmiah Foristek, vol. 2, no.1, pp. 143-152.

Zubaidah, S 2016, 'Keterampilan Abad Ke-21: Keterampilan yang Diajarkan Melalui Pembelajaran', Seminar Nasional Pendidikan Biologi STKIP Persada Khatulistiwa Sintang, pp. 1-17. 